\title{
Между «внутренней» и «внешней» колонизацией. Роман Веры Галактионовой Спящие от печали
}

\section{Between "Internal" and "External" Colonization. Vera Galaktionova's Novel Sorrow Sleepers}

\begin{abstract}
Postcolonial discourse in modern Russian literature is conditioned by the peculiarity of Russian colonization, which was most interestingly characterized by Alexander Etkind in his conception of "internal" and "external" colonization. This conception became the basis of the analyses of the novel Sorrow Sleepers by Vera Galaktionova presented in this article. The action of the novel takes place in a small village in Northern Kazakhstan, inhabited basically by Russians. The perception of the novel based on the conception of "internal" and "external" colonization allows to explicate the connection between the postcolonial trauma and the moral and religious crisis, which hits not only the Russian minority in former Soviet republics, but the Russians in Russia as well.
\end{abstract}

Keywords: postcolonialism, modern Russian prose, Vera Galaktionova, Kazakhstan, Russian, trauma

Abstrakt: Dyskurs postkolonialny we współczesnej literaturze rosyjskiej jest uwarunkowany specyfiką rosyjskiej kolonizacji, którą najciekawiej scharakteryzował Alexander Etkind w swojej koncepcji kolonizacji „,wewnętrznej” i ,zewnętrznej”. Koncepcja ta stanowi podstawę przedstawionych w artykule analiz powieści Spiaszczije ot pieczali [Śpiący ze smutku] Very Galaktionovej. Akcja powieści rozgrywa się w małej wiosce w północnym Kazachstanie, zamieszkanej głównie przez Rosjan. Percepcja powieści oparta na koncepcji kolonizacji „wewnętrznej” i ,zewnętrznej” pozwala wyjaśnić związek postkolonialnej traumy z kryzysem moralnym i religijnym, który dotyka nie tylko mniejszość rosyjską w byłych republikach sowieckich, ale również Rosjan w samej Rosji.

Słowa kluczowe: postkolonializm, współczesna proza rosyjska, Wiera Gałaktionowa, Kazachstan, Rosjanie, trauma

Ключевые слова: постколониализм, современная русская проза, Вера Галактионова, Казахстан, русские травма 
В новейшей русской литературе постколониальный дискурс обусловлен «прежде всего своеобразием русской колонизации, особенностью которой является её двойной характер, включающий помимо внешней ещё и внутреннюю колонизацию» ${ }^{1}$. Данная концепция была выдвинута российским историком и литературоведом Александром Эткиндом, который отмечал, что, в отличие от внешней колонизации, в которой насилие направлено на другие территории и народы, внутренняя колонизация связана с дискриминацией и насилием имперской администрации над низшими сословиями в рамках одного этноса или культуры:

Главные пути российской колонизации направлены не вовне, а внутрь метрополии: Не в Польшу, и даже не в Башкирию, но в тульские, поморские, оренбургские деревни. [...] Россия колонизовала саму себя, осваивала собственный народ. То была внутренняя колонизация, самоколонизация, вторичная колонизация собственной территории ${ }^{2}$.

В другом своем труде, фундаментальной монографии Внутренняя колонизаиия. Имперский опыт России, автор отмечает, что:

В течение столетий Российское государство сочетавло территориальную экспансию с сильной имиграционной политикой. Оно ввозило людей, расселяло и переселяло их, экспериментировало с разными формами управления населением. [...] эти массовые движения перекрывали эластичные континуумы внешнего и внутреннего, туземного и зарубежного, освоенного и чуждого. Зоны более ранней колонизации ощущалисмь как свои - недавно захваченные территории - как все еще иностранные ${ }^{3}$.

Указанная Эткиндом специфика русской колонизации проявлялась на разных уровнях - социальном, политическом, религиозном и, конечно же, культурном. Советский период был лишь её модификацией - традиционные колонизаторские практики большевики подвергли идеологической кодификации, в результате которой на территории СССР было образовано пятнадцать национальных союзных республик, причём советская власть пренебрегала национальными принципами, преследуя экономические, а даже чисто политические цели. Ярким тому примером был процесс формирование среднеазиатских республик - в 1924-1925 гг. советский Туркестан был разделён на пять республик, причем границы устанавливались без учёта исторических факторов и особенностей расселения этнических групп ${ }^{4}$. Так, например, к Казахской ССР присоединили территории, никогда не входившие в состав российского Туркестана и считающиеся русскими, с преобладанием русского же населения - как правило потомков бежавших на эти земли от гонений старообрядцев. Выгнанные репрессивным государством на его окраину, по-

1 Т. Бреева, Постколониальный дискурс в современной русской литературе, «Филология и культура» 2017, № 2(48), с. 140.

2 А. Эткинд, Фуко и тезис о внутренней колонизации: постколониальный взгляд на советское прошлое, «Новое литературное обозрение», № 49, 2001. Электронный адрес: https:// magazines.gorky.media/nlo/2001/3/fuko-i-tezis-vnutrennej-kolonizaczii.html (доступ: 20.04.2021).

А. Эткинд, Внутренняя колонизащия. Имперский опыт России, Москва 2018, с. 382.

${ }^{4}$ Ср.: Д. Тренин, Post-Imperium. Евразийская история, Москва 2012, с. 176. 
сле окончательного краха совесткого имперского проекта, они оказались на чужбине в статусе национального меньшинства.

Казус русских Казахстана интересовал немногих. К их ситуации присматривался Александр Солженицын, которому реалии северного Казахстана были известны по лагерному опыту, однако мнение нобелевского лауреата, выражаемое в ряде публицистических текстов, не получило особого резонанса $^{5}$. Тем более, никакого широкого отклика не получили произведения современной русской писательницы Веры Галактионовой - автора самобытного, независимого, и в связи с этим нарочито и несправедливо замалчиваемого российским литературно-критическим мейнстримом.

Вера Галактионова (1948 г.р.) в 1986 году окончила Литинститут им. Горького, однако, постоянно проживая в Казахской ССР, оставалась в стороне от главных событий бурной перестроечной литературной жизни. После распада Советского Союза Галактионова, вместе с миллионами русских, практически в одночасье оказалась на чужбине, вдалеке от родины. Только к концу 1990-х годов она вернулась в Москву, и с этого момента началось её запоздалое, нелёгкое вхождение в русскую литературу - в 2000 году вышел сборник её прозы Слова на ветру опустевшего века, спустя два года была опубликована повесть Со всеми последующими остановками, а затем в периодике достаточно регулярно стали выходить очередные произведения. На сегодняшний день в России вышло пять книг писательницы, а также трёхтомное собрание сочинений ${ }^{6}$.

Отличительными чертами прозы Галактионовой остаются язык и герои с особым складом характера. Язык в её произведениях разнообразен - то он архаизирован и насыщен сказовой поэтикой старообрядческих говоров (На острове Буяне), то наоборот - современен и органически сочетаем с экспериментальной повествовательной и стилистической формой (роман 5/4. Накануне тишиньl $)^{7}$. С помощью языка формируется и пространство, и характеры героев Галактионовой - они, как правило, люди простые, далёкие от суеты больших городов, близкие к природе. Несмотря на нищету, униженность, бытовую бесперспективность, они отчаянно отстаивают свою честь и достоинство. Сама писательница характеризует персонажей своей прозы следующим образом:

5 См.: А. Солженицын, Как нам обустроить Россию?, «Литературная газета», 18 сентября 1990, № 38, с. 3-6; А. Солженицын, Россия в обвале, Москва 1998, с. 45.

6 В России изданы следующие книги В. Галактионовой: Слова на ветру опустевщего века. Повести, рассказы, очерки, «Московский писатель», Москва 2000, 515 с.; Крылатый дом. Роман, повести, рассказы, «Андреевский флаг», Москва 2003, 575 с.; Спящие от печали. Роман, повести, АСТ «Астрель», Москва 2011, 606 с; На острове Буяне, ИТРК, Москва 2013, 272 с.; Собрание сочинений в трёх томах (т. 1: Восстание праха; т. 2: От четырёх ветров приди; т. 3: Чаша врагу, «Русскій Міръ», ТНИ КМК, Москва, 2014-2018.

7 См.: А. Вавжинчак, Вера в золотое русское время [в:] В. Галактионова, Собрание сочинений в трёх томах, m. 1. Восстание праха. Проза, публицистика, Москва 2014, с.5-8; A. Wawrzyńczak, Człowiek, imperium, historia. O powieści Wiery Gałaktionowej 5/4. „,W przededniu ciszy”, „Przegląd Rusycystyczny”, 2010, nr 1, s. 19-33. 
Да, на смену «плачущему» русскому герою, занимающемуся исключительно похоронами России, я выставляю иной тип людей. Они, чаще всего, красивы, дерзки, умелы, отважны - даже в трагичности, даже в нелепости своих судеб ${ }^{8}$.

В немногих научных и критических работах, посвященных творчеству писательницы, наблюдаются разногласия в определении её позиции в текущем литературном процессе. Итак, критик Капитолина Кокшенёва и филолог Станислав Чумаков относят прозу Глактионовой, и в частности роман Спящие от печали, соответственно, к реализму и психологическому реализму ${ }^{9}$, Яна Сафронова же доказывает, что данное произведение носит черты „патриотического неомодерна"10. Одновременно все три автора подчеркивают христианский, православный стержень галактионовской прозы, что, на наш взгляд, позволяет отнести её творчество к одному из центральных в современной русской литературе течений, а именно традиционализму и продолжающему его в XXI столетии неотрадиционализму ${ }^{11}$. Если же учитывать идеологическую составляющую, проблематику текстов писательницы, основанную на убеждении, что всякие общественно-политичческие перемены должны исходить из нужд Российского государства и народа, а не навязываться извне, то легко заметить связи прозы Галактионовой с наследием Александра Солженицына и Леонида Бородина.

Национал-патриотический фундамент творчества писательиицы определяет своеобразное присутствие в нем постколониального дискурса, что заметно прежде всего в романе Спящие от печали (2011), действие которого развивается на территории сегодняшнего северного Казахстана, в местах, где в сталинское время действовали лагеря, а местные жители в основном работали в учреждениях ГУЛАГ-а. Повествователь также подчеркивает исконную русскость данной территории:

Из южных народов никто и никогда не стремился обосноваться тут для оседлой жизни. Даже на летнее зелёное пастбище сюда не пригоняло скот ни одно из азиатских племён. Всё, всё здесь было слишком необычным для кочевников. [...]

Эта негодная местность считалась у тюрков Воротами ветра, а ветры зарождаются и вертятся духами опасными, непонятными. И лучше проскакать через вихревые

${ }^{8}$ А. Ермакова, Может ли русский быть счастливыл?, «Литературная Россия» 2014, № 39 , c.17.

${ }^{9}$ См.: К. Кокшенёва, Роман-крест Веры Галактионовой. Русские вне русского мира, http://koksheneva.ru/posts/roman-krestverigalaktionovoj/; С. Чумаков, Знаки гибели и надежды, http://www.hrono.ru/proekty/parus/chum0111.php (доступ: 30.06.2021).

${ }^{10}$ См.: Я. Сафронова, Пора лихолетий (Новейшее время в романе Веры Глактионовой «Спящие от печали»), „Подъём”, № 3/2019, http://xn--80alhdjhdcxhy5hl.xn--p1ai/content/pora-liholetiy (доступ: 30.06.2021).

11 Так традиционализм, как неотрадиционализм активно иследуются современным литературоведением, чему примером могут служить следующие труды: Русский традииионализм. История, идеология, поэтика, литературная рефлексия, отв. ред. Н. Ковтун, Москва 2016; Н. Ковтун, Русская традиционалистская проза XX-XXI вв.: генезис, мифопоэтика, контексты. Учебное пособие, Москва 2017; N. Kovtun, N. Klimovich, The Traditionalist discourse on Contemporary Russian Literature: from Neo-traditionalism to “New Realism”, „Umijetnost riječi” 2018, LXII, nr 3-4, c. 315-337; О. Скляров, «В заговоре против пустоты и небытия» Неотрадиционализм в русской литературе ХХ века, Москва 2014. 
Ворота половину суток без передышки, пришпоривая утомившегося коня, но не останавливаться здесь даже на краткий привал ${ }^{12}$.

Земля, непригодная для кочевников, была освоена русскими, бежавшими от „внутренней колонизации” - беглыми сектантами, потомками яицких казаков, каторжниками и со врменем, согласно теории Эткинда, стала восприниматься, как своя, исконно русская. Посреди «Ворот ветра» возник городок Столбцы, в котором, несмотря на тяжёлые природные и бытовые условия жизни оставались жить следующие и следующие поколения потомков его основателей:

Человеческий век этих поселенцев был короче обычного. Но и за быстротечную свою жизнь уставали эти люди отражать, из поколения в поколение, набеги диких кипчакских всадников, бесприютных и жестоких как эти ветры ${ }^{13}$.

Судьба не была ласкова к столбчанам, однако они, согласно названию своего селения ${ }^{14}$, веками сохраняли православную веру, русскую культуру и язык. Со временем Москва, центр империи, становилась для местных жителей всё более абстрактным понятием, приобрела в их сознании особое, грозное значение:

И уж который век в Столбцах самые жестокие и справедливые дети наказывали провинившихся малышей «москвою». Кто-нибудь рослый поднимал шалуна за голову, прижав ладони к его ушам. А когда ноги виноватого отрывались от земли, то карательные жёсткие пальцы за одни только багровеющие уши держали проказника в воздухе, всё выше подтягивая и подтягивая их: «Видал Москву? Видал?» «Вида-аал!» - орал от несусветной боли провинившийся, давясь слезами ${ }^{15}$.

Москва - символ империи, не жалующей своих граждан, и наказание, которое получают дети в Столбцах, наглядно демонстрирует сложившееся веками отношения граждан с их государством. Когда же Столбцы вдруг оказываются за пределами России, жители селения испытывают эсхатологический страх. Их состояние отображено в начальной сцене романа - описание ночных Столбцов, погружённых в сон, создаёт атмосферу близости конца, смерти:

Загодя уснули безработные в щитовых домах, сгрудившихся вокруг громады давно простаивающего горно-обогатительного комбината. [...] Забывшие свои имена, прозываются они все одинаково - чуханы. Нет у них больше возраста и пола. Играют их сонными душами бесьи голоса, морочат воображенье рябые уродливые видения.

В поверхностной дурной дрёме [...] давно не понимают оборванцы ночи и дня, тепла и холода, зла и добра. Умирают потихоньку в привычных грёзах, истаивают в темноте, меркнут их судьбы, задавленные нуждою взрослых.

Спят по разным чуланам и каморкам нищие. [...] Спят в уцелевших жилищах остриженные наголо призывники [...] и отвоевашиеся в Чечне калеки. Спят чистые

12 В. Галактионова, Спящие от печали, Москва 2011, с. 12.

13 Ibid., c. 13.

${ }^{14}$ Столбцы или столбы - в XIV-XVII вв. формам документов, в виде склеенных бумажных полос. Хранились в свёрнутом виде. В таком виде сохранился, наапример оригинал «соборного уловения» 1649 года.

${ }^{15}$ В. Галактионова, op. cit., с. 14-15. 
прилежные школьницы и хворые проститутки. Уставшие продавщицы [...] и тощие учительницы $[\ldots]^{16}$.

Жители поселка, как отмечает К. Кокшенёва, «коренные жители и переселенцы, потомки ссыльных и этузиасты прежних ударно-комсомольских строек» ${ }^{17}$, которые в новообразованном государстве потеряли всё: работу, социальный статус и даже квартиры. Они стали «бывшими», обитают в бараке (временном пристанище), напоминающем ночлежку из горьковской пьесы На дне и как будто бы ждут неизбежной смерти, «спящие от печали», смирившиеся со скорым концом. Апатия, бездействие, чувство обречённости овладели Столбцами окончательно. И всё же надежда на лучшее теплится в их подсознании - неслучайно заголовок романа апеллирует к Евангелию от Луки:

[...] И, выйдя, пошёл по обыкновению на гору Елеонскую, за Ним последовали и ученики Его. Придя же на место, сказал им: молитесь, чтобы не впасть в искушение. И Сам отошёл от них на вержение камня, и, преклонив колени, молился, говоря: Отче! о, если бы Ты благоволил пронести чашу сию мимо Меня! впрочем не Моя воля, но Твоя да будет. Явился же Ему Ангел с небес и укреплял Его. И, находясь в борении, прилежнее молился, и был пот Его, как капли крови, падающие на землю. Встав от молитвы, Он пришёл к ученикам, и нашёл их спящими от печали (выделено А.В.) и сказал им: что вы спите? встаньте и молитесь, чтобы не впасть в искушение ${ }^{18}$.

Казалось бы, жителям Столбцов какое-либо искушение не грозит. Россия, их родина, забыла об их существовании, как будто избавляясь от ненужного постимперского груза. Новые хозяева этой территории - казахи, как правило, молодые, гордые, стремящиеся закрепить свою власть, аппелирующие к достоинству нации и исторической справедливости. Для них русские - чужаки, от которых пора избавиться и забыть про колониальное прошлое. Отметим, что политика властей Казахстана в 90-е годы прошлого века и в начале 2000-х была рассчитана на стимулирование оттока русского и русскоговорящего населения из страны - в её результате в течение первого постсоветского десятилетия Казахстан покинуло полтора миллиона русских ${ }^{19}$.

${ }^{16}$ Ibid, c. 6 .

17 К. Кокшенёва, op. cit.

${ }^{18}$ Евангелие от Луки, гл. 22, 39-46, http://www.my-bible.info/biblio/biblija/ev_luka.html (доступ: 21.04.2021).

19 В период с 1989 по 1999 произошли сущесттвкенные изменения в начиональном составе населения Казахстана. В 1989 году казахи составляли 40\% населения страны (6 млн 564 тысяч чел.), руские жа $38 \%$ (6 млн 228 тыс. чел.). В 1999 году эти цифры выглядели соответтвенно: 53,4\% (7 млн 985 тыс. чел.) и 30\% 4 млн 480 тыс.) Cр.: O. Davydenko, Sytuacja ludności rosyjskojęzycznej współczesnego Kazachstanu na tle przemian demograficznych końca XX i początku XXI wieku, „Zeszyty Naukowe Uniwersytetu Ekonomicznego w Krakowie”, 2011, nr 855, s. 24. По последним данным за 2020 год, предоставленным Коомитетом статистики Министертсва економики Республики Казахстан данные представляются следующе: казахи - 68,51\% (12 млн 755 тыс. чел.), русские 18,85\% (3 млн 513 тыс. чел.). Ср.: Численность Республики Казахстан по отдельным этносам. Демографическая статистика, 21 серия, Қазақстан Республикасы Ұлттық экономика министрлігі Статистика комитеті 2020. Документ доступен на сайте: https:// stat.gov.kz/ (доступ: 30.06.2021). 
По-другому ситуацию воспринимает старшее поколение казахов - старик Жорес, живущий в одном бараке с русскими, считает себя советским человеком. Он чувствует себя чужим на землях, которые Казахстан получил во владение в результате краха империй - сперва царской, а затем советской. Старик критически оценивает новую действительность, в которой, по его убеждению, правят законы торгашества, на продажу выставляется всё, включая патриотизм и любовь к родине:

Там, южнее, в крупных городах, разбогатевших от продажи каких-то ценных бумаг, молодые люди $[\ldots]$ сели в хорошие кресла. Они разговаривают на английском языке по своим карманным телефонам и едят в нарядных ресторанах обильную пищу заморских стран. Но своею страною они торгуют, словно матерью, вот как понимает это старик с революционным именем Жорес ${ }^{20}$.

Иначе новый порядок оценивает внук Жореса. Молодой казах живёт ради собственной выгоды, не стесняясь нравственными принципами - он, как многие его сверстники, в поиске благополучия уходит в криминальные структуры. Когда же юноша на правах «нового хозяина» домогается Нюры, Жорес выгоняет внука из дома, и тот, повинуясь традиционному мусульманскому обычаю уважать старших, покорно выполняет наказ деда. «Советский человек» оказывается нравственно сильнее постколониального нувориша и спасает честь русской девушки.

Вместе с остальными русскими жителями Столбцов Нюра, её муж Иван, их новорождённый сын Саша оказываются в безвыходной ситуации. Они и их соседи - учительница-пенсионерка Сталина Тарасевна и пожилой художник Бухмин - испытывают одиночество, невостребованность, отчуждение. Незнание официального языка и отсутствие образования сильно ограничивают перспективы пары на достойную жизнь - им приходится зарабатывают плетением и продажей похоронных венков. Низкий заработок позволяет им выжить, но не больше - мечты о переезде в Россию остаются только мечтами, само же их занятие скорее вынуждает думать о бренности бытия и смерти, чем надеяться на лучшее, нормальное будущее.

И все же в сонной, подавляющей обстановке пробуждается надежда, которую символизирует образ маленького Саши. Крик ребёнка, разносящийся в ночной темноте, звучит как призыв к жизни, поиску выхода из, казалось бы, тупиковой ситуации. Он напоминает тот самый призыв Христа к ученикам в Гефсимане. Именно так воспринмает плач младенца Бухмин - его старческое, уставшее, но всё ещё чуткое к искусству, красоте, а значит, и к добру, сознание художника позволяет чувствовать больше других.

Где-то в мире, кажется, заплакал ребёнок, отчего поэт Бухмин очнулся раньше времени. Да, сначала прозвучал над ним дикторский голос - кажется, из того самого белого репродуктора, висевшего на стене диспетчерской когда-то, много лет назад: «Сильных поднимет слабый. Он разбудит спящих от печали». [...] «Он победит грабящих. Он уже здесь». А потом раздался маденческий плач ${ }^{21}$.

\footnotetext{
${ }^{20}$ В. Галактионова, op. cit., с. 61.

${ }^{21}$ Ibid., c. 86.
} 
Видение Бухмина эсхатологично - в нём скрывается пророчество о втором пришествии Искупителя и Страшном суде, вызывающее страх, но и вселяющее надежду на чудо, воздаяние за страдания и унижения, пережитые на земле. Правда, религиозность большинства героев романа, воспитанных в условиях атеистической коммунистической системы не прошли бесследно $^{22}$, особенно в местности, прослывшей сталинскими лагерями. Нюра, например, твердит, что Бог был убит «злыми силами», иначе:

[...] Он бы нам помог, если бы живой был. Всем бы помогал. А так... Раз не помогает, значит, погиб 23.

Раз Бога нет, то нет и добра, справедливости и любви, а поэтому и остается только ждать конца, предаваясь страшной экзистенциальной, напоминающей смерть, дремоте. И все же Нюра верит, что её маленького сына ждет другая участь:

Мой дедушка, Саня, говорил, что в чужой жизни не живут, доживают [...]. А я ему верила... Что мы - живые мертвецы. Что нам ничего не положено. И ничего уже не надо... Но ты не думай так... Никогда. Нет... Расти!.. Когда, Саня, за тобой пойдут такие, как мы, ты скажешь про них: им - надо всё наше!... И тебе поверят... Как всегда верят люди тем, кто ищет добра своему народу и кто говорит во благо всего племени своего... Это благо не должно быть меньшим, чем благо других племён... Оно никогда уже не должно быть меньшим... Живи!...24.

В пожеланиях матери младенцу находим всё тот же вероутверждающий призыв из Евангелия от Луки - проснуться, встать на борьбу за своё достоинство, как национальное, так и общечеловеческое, попытаться преодолеть психологическую травму. Политические и экономические законности, приведшие к распаду $\mathrm{CCCP}^{25}$, для них непостижимы, и поэтому отчуждение от родины и статус изгоев на родной по крови и чужой по политическим причинам земле они воспринимают исключительно в духовно-религиозных категориях. Изменить их мышление и судьбу пытается молодой монах Порфирий - правдоискатель, носитель истинной христианской веры, ярый разоблачитаель атеизма и католической веры. Одержимый идеей духовного воскрешения русских, он твердит:

Глаголет Писание: «Проклят нарушающий межи ближнего своего!» Но опять пролез к нам двоедушный папёжник, лукавствующий, сребролюбивый, сквозь наши границы. Не с осьмиугольным византийским истинным: римский четырёхугольный,

22 См.: Д. Поспеловский, Русская православная иерковь в ХХ веке, Москва 1995; Св. А. Федотов, Русская Православная Церковь в 1943-2000 гг.: внутричерковная жизнь, взаимоотнотения с государством и общество (поматериалам Центральной России), Иваново 2005.

${ }^{23}$ В. Галактионова, ор. cit., с. 179.

${ }^{24}$ Ibid, c. $184-185$.

25 Об экономических причинах распада советского государства и коммунистического строя писали многие авторы, однако наиболее объективный, экспертный, а вто же время предельная ясны анализ был предложен Егором Гайдаром в нескольких книгах. См. Е. Гайдар, Гибель империи. Уроки для современной России, Москва 2006; Е. Гайдар, Долгое время. Россия в мире. Очерки экономической истории, Москва 2005. 
усечённый крыж в деснице его! [...] Вот она оказалась какая, разъединившая нас, разорившая, размоловшая судьбы людские в пыль... ${ }^{26}$

В словах Порфирия звучит многовековое противостояние православия западному христианству и шире - западной цивилизации. На протяжении веков духовенство и идеологи российского государства предостерегали от «неправильных, опасных» идей, проникающих в Россию из Европы. В романе Галактионовой эта извечная борьба с противником, проникающим «извне», приобретает эсхатологический смысл. В маленьком пространстве Столбцов концентрируется весь комплекс кризисных проблем, вопросов, касающихся судеб народа и страны. Причины кризиса понятны - крах ложной, антихристианской коммунистической идеи, потянувший за собой крах империи и имперского сознания, являющегося, по мнению писательницы, сутью русского менталитета ${ }^{27}$. Порфирий же видит спасение, надежду на возрождение травмированного жестокими экспериментами XX века народа, в возврате к вере.

Показательно, что отчаявшийся монах обращается не к представителям политической и экономической элиты, но ищет поддержки своим мыслям у «унижённых и оскорблённых» обитателей барака. В младенце Саше он сразу узнаёт будущего воина-спасителя, и под влиянием этого видения наачинает вести агитацию среди юного поколения. В котельной заброшенного металлургического завода монах встречает коммуну беспризорных ${ }^{28}$ и, словно во времена катакомбного христианства, начинает проповедовать среди них слово Божье, однако не может дать отчаянным и дерзким подросткам ясный ответ на тревожащий их вопрос: как жить? Его проповедь подростки воспринимают как агрессивное вмешательство в их жизнь и отвечают, естественно, тем же:

[...] А ну, вали отсюда! - ломко прокричал он (мальчик - А.В.), замахиваясь на Порфирия гвоздодёром, и крупные глаза его сделались белыми. [...]

[...] пухлощёкий мальчик высунул голову из-под шубы.

- Ты, глюк, вали! - закричал он вдруг на Порфирия, взвизгивая и капризничая - Вали отсюда, глюк!

Перекрестившись, Порфирий побрёл к выходу. «Милостивый! Прости мя, яко немощен есмь - молился он духом. - Не разумею, как должно поступать... Ничего не разумею...» ${ }^{29}$.

${ }^{26}$ В. Галактионова, op. cit., с. 219.

${ }_{27}$ См.: А. Ермакова, Может ли русский быть счастливым?, «Литературная Россия» 2014, № 39, c. 18 .

${ }^{28}$ О проблеме беспризорных и безнадзорных детей в России и странх СНГ смотри: Т. Сидорова, Беспризорные дети в России и в мире. Взгляд сочиолога, Москва 2010; М. Нечаева, Детская беспризорность - опасное сочиальное явление, „Государство и право” 2001, № 6, с. 57-65. В русской литературе тема беспризорных появлялась довольно часто в советский период, в творчестве таких авторов как Антон Макаренко, Вячеслав Шишков, Анатолий Рыбаков, Анатолий Приставкин и другх. В новейшей русской литературе отметим произведение Владимира Шарова Будьте как дети (2008) и последний роман Гузели Яхиной Эмелон на Самарканд (2021).

29 В. Галактионова, оp. cit., с. 248. 
Ожесточение детей под влиянием трагического жизненного опыта - ещё один показатель глубокого социально-нравственного кризиса общества первых лет постсоветской действительности, и также того, что постколониальной травме подверглись все поколения. Беспризорники тоже «спят от печали», однако, в отличие от взрослых, не воспринимают свою ситуацию как ощущение конца - для них это просто жизнь, другой они не знают, проповеди же Порфирия воспринимают как видение, галлюцинацию.

Подавленный пережитым монах покидает Столбцы и отправляется в Россию, на «большой материк». Там, в отдалённой обители, переживает несколько видений, утвердивших его в необходимости нести людям веру во спасение и возрождение нации. Его возвращения ожидают и жители Столбцов - некоторые из них регулярно видят монаха в своих снах, и образ его сопровождается словами из Добротолюбия:

Как есть чаша падения и чаша гнева,

так есть и чаша немощи,

которую, прияв от нас, Господь

в подобавшее время даёт в руки врагов наших,

чтобы прочее не мы, а бесы немоществовали

и падали ${ }^{30}$.

Порфирий из сновидения продолжает цитату словами, которые и завершают роман:

[...] «Много нас, много, вытесненных отовсюду, да утешены будем на небесах самой высокой милостью, какой не найти нам на земле...»³.

Финал романа неоднозначен - история жителей городка, затерянного на окраинах империи, легко может быть прочитана как метафора судеб многих русских, оказавшихся после распада империи на территории Казахстана. Их можно считать жертвами сразу двух типов колонизации - внутренней, от которой некогда их предки скрылись в среднеазиатских степях, и внешней ведь именно как колонизаторов они воспринимают казахов, «хозяев» новообразованного государства, в котором оказались вопреки своей воле. Испытываемое ими чувство безысходности усугубляется отсутствием авторитета, лидера, которому они могли бы доверить свою судьбу. По этому поводу Тарасевна делится с Бухминым показательным замечанием:

- А я точно знаю, за что мы теперь миллионами помираем! [...] Чужих вождей мы выучили, а своего-то вождя, заступника своего, не догадались взрастить! Народного, нашего. Настоящего... ${ }^{32}$

Отсутствие национального лидера - ещё один признак постколониальной травмы, наблюдаемый в российском обществе в 90-е годы прошлого века. Жители Столбцов ждут своего лидера, спасителя, однако видят его лишь в будущем, а не в действующих элитах - потому все свои надежды

\footnotetext{
30 Ibid., c. 326 .

31 Ibid.

32 Ibid., c. 273.
} 
они обращают к маленькому Саше. Их мечта отдалена во времени и требует терпения и смирения. Призыв сохранять обе эти добродетели и есть суть эсхатологического, исихастического романа Веры Галактионовой. Спасение русской цивилизации и русской нации кроется не в борьбе, воинствующем реваншизме, революционных порывах - оно хранится в постепенном духовном возрождении и развитии. Возрождение нации требует усилий многих поколений. Для этого и рождаются такие, как Саша-воин, - воин не с мечом, не со связкой гранат в руке и щетиной ракетных установок, а воин-духовник - умный, образованный, честный и неподкупный, почитающий своих предков, родину и национально-христианские и общечеловеческие традиции.

Роман Спящчие от печали - произведение с философско-религиозным стержнем, затрагивающее широкий спектр проблем, волнующих современное общество, прежде всего вопрос «выживания народа и его самоидентификации в условиях внутренней катастрофы и предательства правителей» ${ }^{33}$. Постколониальный дискурс прочитывается в нём не сразу, потому его нельзя назвать центральным. Однако постколониальная перспектива даёт возможность интерпретировать данное произведение как предостережение от попыток реваншизма и проб возродить империю путём волевых, непродуманных политических действий. Выход из постколониальной травмы для русских видится не только в переосмыслении своей истории, но, прежде всего в возврате к нравственно-духовным основам русской цивилизации - по словам К. Кокшенёвой, «народ должен научиться слушать себя» ${ }^{34}$. Российское общество ждёт сложная и долгосрочная работа над собственным сознанием, которая в тридцатилетний уже период постимперского существования страны так и не была проведена. Роман Веры Галактионовой безоговорочно подтверждает необходимость пройти сложный путь преодоления постимперских комплексов - пройти до конца, не оглядываясь на прошлое, во благо будущих поколений. Только в этом случае Россия сможет стать державой, но не той, которая вызывает страх у соседей и геополитических конкурентов, а той, которая сможет предложить новое, основанное на христианской справедливости и уважении к каждой нации и культуре, качество жизни как своим гражданам, так и международному сообществу.

\section{Библиография}

Бреева Т., Постколониальньй дискурс в современной русской литературе, «Филология и культура» 2017, № 2(48), с. 140.

Вавжинчак А., Вера в золотое русское время [в:] В. Галактионова, Собрание сочинений в трёх томах, т. 1. Восстание праха. Проза, публицистика, Москва 2014.

\footnotetext{
33 С. Чумаков, ор. cit.

${ }^{34}$ К. Кокшенёва, op. cit.
} 
Гайдар Е., Гибель империи. Уроки для современной России, Росспен, Москва 2006.

Гайдар Е., Долгое время. Россия в мире. Очерки экономической истории, Москва 2005.

Галактионова В., Спящие от печали, Москва 2011.

Евангелие от Луки, http://www.my-bible.info/biblio/biblija/ev_luka.html (доступ: 30.06.2021).

Ермакова А., Может ли русский быть счастливыл?, «Литературная Россия» 2014, № 39 .

Ковтун Н., Русская традиционалистская проза XX-XXI вв.: генезис, мифопоэтика, контексты. Учебное пособие, Москва 2017.

Кокшенёва К., Роман-крест Веры Галактионовой. Русские вне русского мира, http://koksheneva.ru/posts/roman-krestverigalaktionovoj/ (доступ: 30.06.2021).

Нечаева М., Детская беспризорность - опасное социальное явление, „Государство и право” 2001, № 6, с. 57-65.

Поспеловский Д., Русская православная церковь в ХХ веке, Москва 1995.

Русский традиционализм. История, идеология, поэтика, литературная рефлексия, отв. ред. Н. Ковтун, Москва 2016.

Сафронова Я., Пора лихолетий (Новейшее время в романе Веры Глактионовой «Спящие от печали»), „Подъём” 2019, № 3, http://xn--80alhdjhdcxhy5hl.xn-p1ai/content/pora-liholetiy (доступ: 30.06.2021).

Сидорова Т., Беспризорные дети в России и в мире. Взгляд соичиолога, Москва 2010.

Скляров О., «В заговоре против пустотьл и небытия» Неотрадиичонализм в русской литературе XX века, Москва 2014.

Солженицын А., Как нам обустроить Россию?, «Литературная газета», 18 сентября 1990 , № 38, с. 3-6.

Солженицын А., Россия в обвале, Москва 1998.

Тренин Д., Post-Imperium. Евразийская история, Москва 2012.

Федотов А., Русская Православная Церковь в 1943-2000 г2.: внутрииерковная жизнь, взаимоотношения с государством и общество (поматериалам Центральной России), Иваново 2005.

Численность Республики Казахстан по отдельным этносам, «Демографическая статистика. 21 серия», Қазақстан Республикасы Ұлттық экономика министрлігі С татистика к омитеті 2020, https://stat.gov.kz/ (доступ: 30.06.2021).

Чумаков С., Знаки гибели и надежды, http://www.hrono.ru/proekty/parus/chum0111. php (доступ: 30. 06. 2021).

Чупринин С., Большой путеводитель. Русская литература сегодня, Москва 2007.

Эткинд А., Внутрення колонизация. Имперский опьт России, Москва 2018.

Эткинд А., Фуко и тезис о внутренней колонизации: постколониальный взгляд на советское прошлое, «Новое литературное обозрение» 2001, № 49, 2001, c. 50-74; https://magazines.gorky.media/nlo/2001/3/fuko-i-tezis-vnutrennej-kolonizaczii.html (доступ: 30.06.2021). 
Davydenko O., Sytuacja ludności rosyjskojęzycznej współczesnego Kazachstanu na tle przemian demograficznych końca XX i początku XXI wieku, „Zeszyty Naukowe Uniwersytetu Ekonomicznego w Krakowie", Kraków 2011, nr 855, s. 21-34.

Kovtun N., Klimovich N., The Traditionalist Discourse on Contemporary Russian Literature: from Neo-traditionalism to “New Realism”, „Umijetnost riječi” 2011, LXII, nr 3-4, s. 315-337.

Wawrzyńczak A., Człowiek, imperium, historia. O powieści Wiery Gałaktionowej „,5/4. W przededniu ciszy”, „Przegląd Rusycystyczny”, 2010, nr 1, s. 19-33.

\section{References}

Breeva T., Postkolonial'nyj diskurs v sovremennoj russkoj literature, «Filologiya i kul'tura» 2017, № 2(48), s. 140 .

Vavzhinchak A., Vera v zolotoe russkoe vremya [v:] V. Galaktionova, Sobranie sochinenij v tryoh tomah, t. 1. Vosstanie praha. Proza, publicistika, Moskva 2014.

Gajdar E., Gibel'imperii. Uroki dlya sovremennoj Rossii, Moskva 2006.

Gajdar E., Dolgoe vremya. Rossiya v mire. Ocherki ekonomicheskoj istorii, Moskva 2005.

Galaktionova V., Spyashchie ot pechali, Moskva 2011.

Evangelie ot Luki, http://www.my-bible.info/biblio/biblija/ev_luka.html (dostup: 30.06.2021).

Ermakova A., Mozhet li russkij byt‘ schastlivym?, «Literaturnaya Rossiya» 2014, № 39 .

Kovtun N., Russkaya tradicionalistskaya proza XIX - XXI vv.: genezis, mifopoetika, konteksty. Uchebnoe posobie, Moskva 2017.

Kokshenyova K., Roman-krest Very Galaktionovoj. Russkie yne ruskogo mira, http:// koksheneva.ru/posts/roman-krestverigalaktionovoj/ (dostup: 30.06.2021).

Nechaeva M., Detskaja besprizornost' - opasnoe social'noe javlenie, „Gosudarstvo i pravo" 2001, № 6, s. 57-65.

Pospelovskij D., Russkaya pravoslavnaya cerkov ‘v XX veke, Moskva 1995.

Russkij tradicionalizm. Istoriya, ideologiya, poetika, literaturnaya refleksiya, otv. red. N. Kovtun, Moskva 2016.

Safronova YA., Pora liholetij (Novejshee vremya v romane Very Galaktionovoj «Spyashchie ot pechali»), „Pod”yom” 2019, № 3, http://xn--80alhdjhdcxhy5hl.xn-plai/content/pora-liholetiy (dostup: 30.06.2021).

Sidorova T., Besprizornye deti v Rossii i v mire. Vzglyad sociologa, Moskva 2010.

Solzhenicyn A., Kak nam obustroit' Rossiyu?, «Literaturnaya gazeta», 18 sentyabrya 1990, № 38, s. 3-6.

Solzhenicyn A., Rossiya v obvale, Moskva 1998.

Trenin D., Post-Imperium. Evrazijskaya istoriya, Moskva 2012.

Chislennost' Respubliki Kazahstan po otdel'nym etnosam, «Demograficheskaya statistika. 21 seriya», Kazakhstan Respublikasy Ulttyk ekonomika ministrligi Statistika komiteti 2020, https://stat.gov.kz/ (dostup: 21.04.2021).

Chuprinin S., Bol'shoj putevoditel'. Russkaya literatura segodnya, Moskva 2007.

Etkind A., Vnutrennya kolonizaciya. Imperskij opyt Rossii, Moskva 2018. 
Etkind A., Fuko i tezis o vnutrennej kolonizacii: postkolonial'nyj vzglyad na sovetskoe proshloe, «Novoe literaturnoe obozrenie» 2001, № 49, s. 50-74, https://magazines.gorky.media/nlo/2001/3/fuko-i-tezis-vnutrennej-kolonizaczii.html (dostup: 21.04.2021).

Davydenko O., Sytuacja ludności rosyjskojęzycznej współczesnego Kazachstanu na tle przemian demograficznych końca XX i początku XXI wieku, „Zeszyty Naukowe Uniwersytetu Ekonomicznego w Krakowie”, 2011, nr 855, s. 21-34.

Kovtun N., Klimovich N., The Traditionalist discourse on Contemporary Russian Literature: from Neo-traditionalism to “New Realism”, „Umijetnost riječi”, LXII (2018), nr 3-4, s. 315-337.

Wawrzyńczak A., Człowiek, imperium, historia. O powieści Wiery Gałaktionowej „5/4. W przededniu ciszy”, „Przegląd Rusycystyczny”, 2010, nr 1, s. 19-33. 